\title{
DAMPAK NEGATIF PERKEMBANGAN TEKNOLOGI INFORMATIKA DAN KOMUNIKASI DAN CARA ANTISIFASINYA
}

\author{
Oleh \\ I Gede Ratnaya \\ Jurusan Teknik Elektronika, FTK, UNDIKSHA
}

\begin{abstract}
ABSTRAK
Sampai saat ini perkembangan ilmu pengetahuan telah menghantarkan masyarakat menuju babak baru yaitu babak yang memanfaatkan peralatan-peralatan yang merupakan hasil dari teknologi. Penggunaan tenaga manusia yang semakin hari semakin kecil volumenya sering kali menyebabkan orang kehilangan pekerjaannya karena tugasnya telah tergantikan oleh peralatan atau mesin. Sebagai sarana penyampaian informasi dan komunikasi, komputer bisa dipakai sebagai sarana berinternetan. Lewat internet orang bisa mencari bermacam-macam informasi dan berkomunikasi. Peran yang dapat diberikan oleh aplikasi teknologi informasi ini adalah mendapatkan informasi untuk kehidupan pribadi seperti informasi tentang kesehatan, hobi, rekreasi, dan rohani. Selain memberikan keuntungan, ternyata peralatan teknologi informasi dan komunikasi juga memberikan dampak negatif bagi penggunanya. Dampak negatif tersebut muncul sebagai akibat dari penggunaan yang salah atau tidak bertanggung jawab dari yang menggunakan. Beberapa dampak negatif tersebut adalah 1). Anak lebih banyak menghabiskan waktu menonton TV ketimbang melakukan hal lainnya (seperti belajar dan olah raga), 2). Anak kehilangan kemampuan berbaur dengan masyarakat dan cenderung nyaman dengan kehidupan online, 3) Adanya pelanggaran hak cipta, 4). Kejahatan di internet, 5). Penyebaran virus komputer, dan 6). Pornografi, perjudian, penipuan, tayangan kekerasan. Adapun cara mengatasi dampak-dampak negatif tersebut adalah : 1). Gunakan teknologi untuk menjalin hubungan dengan orang yang sudah dikenal, 2). Cari komunitas positif yang sering melakukan pertemuan didunia nyata, 3). Perlunya penegakkan hukum yang berlaku dengan dibentuknya polisi internet, 4). Menghindari pemakaian telepon seluler yang berfitur canggih oleh anak-anak dibawah umur dan lebih mengawasi penggunaan telepon seluler, 5). Perbanyak membaca buku-buku yang bersifat edukatif dan bersifat keimanan serta aplikasi komputer yang bersifat mendidik, dan 6). Perlunya pengaturan waktu untuk berada di depan komputer atau televisi.
\end{abstract}

Kata kunci : informasi, komunikasi, perkembangan teknologi

\begin{abstract}
Until recently the development of science have exposed the public to the new round is the round that utilizes equipment that is the result of technology. The use of human labor that is increasingly smaller volumes often cause people to lose his job
\end{abstract}


because his job has been replaced by equipment or machinery. As a means of delivering information and communication, computers can be used as a means berinternetan. Through the internet people can find a variety of information and communication. Roles that can be provided by the application of information technology is getting information to your personal life such as information about health, hobbies, recreation, and spiritual. In addition to providing benefits, it turns out the information and communication technology equipment also adversely affect our users. Negative impacts arise as a result of misuse or irresponsible use of the. Some negative effects are 1). Children spent more time watching TV than doing anything else (such as learning and exercise), 2). Children lose the ability to blend in with society and tend to be comfortable with online life, 3) the existence of copyright infringement, 4). Crime on the Internet, 5). The spread of computer viruses, and 6). Pornography, gambling, fraud, violent impressions. As for how to overcome the negative effects are: 1). Use technology to engage programs so people who are well known, 2). Find a positive community that is often met in the real world, 3). The need for law enforcement with the creation of the internet police, 4). Avoiding the use of mobile phones that feature advanced by children under the age of and greater control over their use of mobile phones, 5). Expand to read books that are educational and the nature of faith as well as computer applications that are educational, and 6). The need for setting the time to be in front of a computer or television.

Keywords : information, communication, development of technology

\section{PENDAHULUAN}

Sampai saat ini perkembangan ilmu pengetahuan telah menghantarkan masyarakat menuju babak baru yaitu babak yang memanfaatkan peralatan-peralatan yang merupakan hasil dari teknologi. Peralatan-peralatan tersebut tidak hanya bisa membantu secara langsung pekerjaan-pekerjaan kita dalam melaksanakan aktivitas tetapi juga bisa memberikan informasi dan menghibur kita. Dengan adanya peralatan tersebut, kita mulai termajakan sehingga gerakan tubuh kita menjadi semakin pasif. Penggunaan akan tenaga manusia semakin lama semakin kecil volumenya.

Penggunaan tenaga manusia yang semakin hari semakin kecil volumenya sering kali menyebabkan orang kehilangan pekerjaannya karena tugasnya telah tergantikan oleh peralatan atau mesin. Kian hari penomena ini akan semakin menjadi-jadi karena penciptaan akan peralatan yang memudahkan manusia semakin 
banyak dan malahan di negara-negara industri seperti Jepang, China, Amerika, Jerman, dan negara industri di benua Eropa penciptaan akan peralatan-peralatan ini tidak terbendung. Indonesia menjadi sasaran yang empuk bagi negara-negara industri tersebut untuk memasarkan produk-produknya. Salah satu peralatan tersebut adalah komputer.

Komputer saat ini telah merambah di segala lini kehidupan. Di perusahaanperusahaan, kantor-kantor baik swasta maupun negeri telah memanfaatkan komputer untuk mempermudah dan mempercepat pekerjaannya. Saat ini komputer juga bisa sebagai sarana penghibur bagi penggunanya. Lewat komputer, orang bisa mendengarkan lagu-lagu, menonton film, dan bermain game. Yang paling ngetren saat ini adalah komputer sebagai sarana penyampaian informasi dan komunikasi. Sebagai sarana penyampaian informasi dan komunikasi, komputer bisa dipakai sebagai sarana berinternetan

Menurut Wildan (2008), dalam sejarah peradaban manusia kita mengetahui bahwa kemajuan masyarakat dicapai melalui beberapa tahapan yaitu : 1). Pada awal mulanya manusia berkomunikasi hanya dengan isyarat atau tanda-tanda atau lambang-lambang, tetapi dalam perkembangan manusia kemudian menciptakan dan menggunakan bahasa dalam berkomunikasi, 2). Manusia mulai menggunakan aksara yang berkembang dari Pictograph ke Hieroglyp dan menjadi Ideograph., 3). Komunikasi dan pertukaran informasi dengan menggunakan aksara itupun semakin maju setelah menggunakan mesin cetak pada abad 15 oleh J. Gutenberg. Dengan penemuan mesin cetak tersebut komunikasi masa mulai dapat dilakukan dengan terbitnya surat kabar yang kemudian disusul oleh hadirnya radio, film dan televisi, 4). Ditemukannya komputer yang mempermudah dan mempercepat manusia dalam mengolah informasi, 5). Digabungkannya penggunaan komputer dengan telekomunikasi. Pada tahap inilah arti teknologi informasi yang sebenarnya yaitu teknologi yang menggabungkan komputer

Di era ini, keberadaan Teknologi Informasi dan Komunikasi (TIK) yang diterapkan secara sesuai, tepat, terencana dan berkelanjutan tidak hanya diyakini, 
tetapi di berbagai negara juga terbukti berhasil membawa percepatan kemajuan di berbagai bidang kehidupan. Kebangkitan IT untuk masa depan yang lebih baik, hendaknya disadari oleh generasi muda Indonesia, yang akan menjadi tulang punggung pengembangan bangsa di masa mendatang. Untuk itu diperlukan adanya upaya untuk menumbuh kembangkan ketertarikan dan perluasan wawasan generasi muda terhadap TIK.

Teknologi informasi tidak lepas dari dunia maya alias internet. Internet bagian dari kehidupan tidak bisa dihindari, internet akan mengglobal dan akan terus berkembang, sulit rasanya menjadi bagian dunia di masa depan jika kita tidak ikut memanfaatkannya. Komputer ada di mana-mana, semakin portable dan mobile. Ketersediaan jaringan internet sangat tinggi karena itu akses terhadap informasi dapat dilakukan di manapun dan kapanpun. Internet akan mengandung informasi yang berlimpah. Manusia dapat bekerja, menikmati hiburan, bersosialisasi dan berkelana secara virtual ke seluruh dunia tanpa harus beranjak dari tempat duduknya. Robot-robot cerdas akan melayani seluruh kebutuhan manusia. Manusia dapat melakukan berbagai hal dengan upaya fisik yang sangat minimum. Dua hal kunci adalah: cyberspace atau dunia virtual, anytime anywhere access dan minimalisasi aktifitas fisik.

Jumlah pengguna internet yang besar dan terus berkembang telah mewujudkan budaya baru. Internet telah memberikan pengaruh yang besar terhadap ilmu pengetahuan dan pandangan dunia. Dengan hanya berpandukan mesin pencari seperti Google dan Yahoo!, pengguna di seluruh dunia mempunyai akses yang mudah atas bermacam-macam informasi. Internet bisa menjadi komplemen dari buku dan perpustakaan di dunia nyata. Internet mampu menjadi penyedia fasilitas dunia pendidikan. Perkembangan internet juga telah memengaruhi perkembangan ekonomi. Berbagai transaksi jual beli yang sebelumnya hanya bisa dilakukan dengan cara tatap muka (atau melalui pos atau telepon), kini sangat mudah dan sering dilakukan melalui internet. Transaksi melalui internet itu dikenal dengan nama ecommerce. 
Terkait dengan pemerintahan, internet memicu tumbuhnya transparansi pelaksanaan pemerintahan melalui e-government. Juga, peningkatan pelayanan publik. Sampai saat ini hampir $75 \%$ pemerintah daerah Indonesia sudah memiliki situs resmi sendiri. Namun untuk mencapai kondisi yang diharapkan masih diperlukan banyak perbaikan.

Dengan melihat betapa penting peran internet di masa yang akan datang pemerintah Indonesia diharapkan mampu meningkatkan akses internet masyarakat. Idealnya seluruh penduduk Indonesia harus melek internet. Pemerintah pun sudah mempunyai target, pada 2015, 50\% desa-desa bakal terkoneksi dengan ICT (information \& communication technology). Namun banyak kendala yang menghadang. Salah satunya infrastruktur. Teledensitas akses komunikasi di wilayah perdesaan Indonesia menurut data Direktorat Jenderal Pos dan Telekomunikasi baru mencapai $0,2 \%$. Jumlah desa yang belum terjangkau oleh telepon masih 44.809 dari total 76.959 desa. Pembangunan infrastruktur telekomunikasi di Indonesia memang tidak semudah negara tetangga. Baik segi biaya dan implementasi. Mengingat geografis Indonesia jauh lebih luas dan berpulau-pulau. Apalagi negara ini sedang mengalami krisis berkepanjangan sehingga dana yang tersedia pun sangat minim. Karena itu, masuknya lembaga swadaya masyarakat (LSM) dan swasta di sektor itu sangat diharapkan. Namun, pemerintah harus

\section{PEMBAHASAN}

\section{Dampak Perkembangan Teknologi Informasi Dan Komunikasi}

Di zaman sekarang ini penggunaaan IT sudah tidak dapat dihindari lagi atau sudah tidak terpisahkan. TIK yang semula merupakan pilihan, sekarang menjadi kebutuhan. Contohnya seperti : 1). Hp ( sellular ) yang mulai dikenal dari tahun 1988 yang merupakan pilihan dan bukan suatu kebutuhan. Pertama kali dikeluarkan oleh Motorola 8000x ( Dynatac ) yang systemnya masih analog dan mudah disadap. Hingga tahun 1994 penggunaan Hp masih tetap hanya menjadi pilihan. Dan tahun 1998 lebih tepatnya pada saat kerusuhan yang terjadi di Indonesia, saat itu merupakan titik balik dimana penggunaan Hp yang tadinya 
merupakan pilihan menjadi kebutuhan, 2). Notebook dahulu juga merupakan pilihan dan sekarang juga berubah menjadi suatu kebutuhan.

Perkembangan Teknologi dan informasi pada saat ini tidak hanya pada komputer saja. Televisi juga merupakan sarana telekomunikasi yang perkembangannya sangat cepat. Karena kita tahu televisi sekarang ini bukan menjadi kebutuhan mewah tapi sebagai kebutuhan pokok. Hampir disetiap rumah mempunyai TV meskipun tidak sebagus TV orang kaya. Sebagian besar orang akan menghabiskan waktu luangnya untuk menonton TV, terutama pada anak-anak.

Internet secara gampangnya dapat di artikan sebagai suatu jaringan komputer yang sangat luas, sehingga setiap pengguna komputer dapat berinteraksi dengan komputer lain di seluruh dunia ( yang berisikan informasi dan lain-lain ). Adapun dampak positif dari internet :

a. Media komunikasi : dengan internet kita dapat berkomunikasi dengan seseorang / sekelompok rang dimana saja dengan mudah. Aplikasi yang mendukung komunikasi via internet antara lain : Yahoo messenger,Google Talk,dan Aplikasi chatting yang sangat banyak jumlahnya.

b. Media pertukaran data : Kita dapat mengirim dan menerima data dengan mudah, contohnya dengan menggunakan e-mail,newsgroup,dan situs - situs lainnya.

c. Media untuk mencari informasi dan berita : banyak sekali berita yang kita dapatkan di internet ataupun informasi apapun dapat dengan mudah kita jumpai, apalagi banyak program searc engine macam google,yahoo,dll yang makin memanjakan kita.

d. Media untuk bisnis : Banyak macam-macam cara yang digunakan untuk berbisnis di internet,antara lain berjualan suatu produk yang kita iklankan di web / blog, membuat situs yang menarik sehingga ada perusahaan yang tertarik mengiklankan produknya di halaman kita, dll. 
e. Media untuk hubungan Sosial: Aplikasinya berupa social networking seperti Facebook, Twitter, Plurk, MySpace dll.

f. Hiburan : banyaknya game online yang bertebaran di internet.

Selain memberikan keuntungan, ternyata peralatan teknologi informasi dan komunikasi juga memberikan dampak negatif bagi penggunanya. Dampak negatif tersebut muncul sebagai akibat dari penggunaan yang salah atau tidak bertanggung jawab dari yang menggunakan. Bagaimana tidak, belakangan ini masyarakat lebih nyaman mengumpulkan teman-teman didunia maya daripada aktif pada kegiatankegiatan organisasi riil yang dapat memberikan kualitas hubungan pertemanan yang lebih kongkrit dan intents.

Dampak negatif dari perkembangan teknologi informasi dan komunikasi tersebut antara lain :

a. Anak lebih banyak menghabiskan waktu menonton TV ketimbang melakukan hal lainnya (seperti belajar dan olah raga). Dengan kesibukan orangtua yang tidak punya waktu yang cukup untuk memerhatikan, mendampingi \& mengawasi anak. Anak lebih banyak menghabiskan waktu menonton TV. Dalam seminggu anak menonton TV sekitar 170 jam. Apa yang mereka pelajari selama itu? Mereka akan belajar bahwa kekerasan itu menyelesaikan masalah. Mereka juga belajar untuk duduk di rumah dan menonton, bukannya bermain di luar dan berolahraga. Hal ini menjauhkan mereka dari pelajaran-pelajaran hidup yang penting, seperti bagaimana cara berinteraksi dengan teman sebaya, belajar cara berkompromi dan berbagi di dunia yang penuh dengan orang lain.

b. Anak kehilangan kemampuan berbaur dengan masyarakat dan cenderung nyaman dengan kehidupan online. Banyak orang yang memiliki ratusan atau bahkan ribuan teman difacebook tapi di dunia nyata, mereka hanya memiliki beberapa orang teman dekat yang menemani keseharian mereka. . Padahal jika terjadi suatu hal yang krusial pada kehidupan kita, yang bisa membantu 
kita bukanlah orang-orang yang kita kenal didunia maya tapi orang-orang yang hidup disekitar kita.

c. Pelanggaran Hak Cipta, Hak Kekayaan Intelektual (HaKI) adalah hak eksklusif yang diberikan suatu peraturan kepada seseorang atau sekelompok orang atas karya ciptanya. HaKI mencakup dua katagori yaitu Hak Cipta dan Hak Kekayaan Indutri. Hak Cipta adalah hak eksklusif bagi pencipta maupun penerima hak untuk mengumumkan atau memperbanyak ciptaannya maupun memberikan izin untuk itu dengan tidak mengurangi pembatasan menurut peraturan undang-undang yang berlaku. Sedangkan Hak Kekayaan Industri meliputi paten, merek, desain industri, desain tata letak sirkuit terpadu, rahasia dagang dan varietas tanaman. Undang-undang yang mengatur Hak Cipta adalah Undang-undang No. 19 tahun 2002 yang menjelaskan beberapa bentuk ciptaan yang dilindungi terdiri dari berbagai bidang seperti ilmu pengetahuan, seni dan sastra. Di dalam peraturan hak cipta ada beberapa hak yang didapatkan oleh seseorang atau beberapa orang yang secara hukum telah menjadi pemegang hak cipta, yaitu hak ekslusif, hak ekonomi dan hak moral. Hukuman atau sanksi yang diberikan bagi pelanggar Hak Cipta, adalah tuntutan hukuman pidana ataupun gugatan perdata.

d. Kejahatan di Internet. Kejahatan ini tidak mengenal batas negara dan teritorial, kapan pun dan di manapun bisa muncul. Perbuatan yang dilakukan tersebut bersifat ilegal atau tidak etis, menggunakan peralatan yang berhubungan dengan komputer dan internet, dan Kerugian yang diakibatkan jauh lebih besar daripada kejahatan biasa. Biasanya pelaku kejahatan adalah orang yang mengerti dan memahami dengan baik tentang internet, komputer dan berbagai aplikasinya. Jenis-jenis kejahatan di internet: Unauthorized Access, Cyber Sabotage and Extortion, Cyber Espionage, Data Forgery, Illegal Contents, Infrigements of Privacy, Phising, Spamming, Offense Againts Intellectual Property, dan Carding. 
e. Penyebaran Virus Komputer. Virus komputer adalah sebuah program yang berukuran relatif kecil dan bersifat sebagai parasit yang mampu hidup dan menggandakan dirinya menyerupai file maupun folder dan sangat mengganggu pengguna komputer yang terinfeksi. Virus komputer meyebar melalui berbagai media termasuk media internet dan penyimpanan (file storage) seperti CD-ROM, Disket, Flash Disk, Hard Disk, dan Memory Card.

f. Pornografi, perjudian, penipuan, tayangan kekerasan. Berbagai peralatan TIK seperti TV, internet, banyak menayangkan dan menampilakan tindakantindakan pornografi, perjudian, penipuan, dan tayangan kekerasan yang dengan cepat ditiru para penikmatnya.

\section{Cara Mengantisifasi Dampak Negatif Penggunaan Teknologi Informasi Dan Komunikasi}

Kemajuan teknologi informasi tidak mungkin ditolak tetapi harus dapat dimanfaatkan agar tidak tersisih dari tata pergaulan masyarakat dunia. Salah satu jalan agar teknologi informasi dapat dimanfaatkan adalah dengan memberdayakan masyarakat karena semakin tidak berdaya masyarakat maka dampak negatif akan muncul dan merusak kehidupan. Pemberdayaan masyarakat dapat dilakukan dengan cara : 1) Mengenalkan tekologi informasi sekaligus manfaatnya bagi kehidupan sosial kemasyarakatan, 2) Menghilangkan gagap teknologi dan rasa minder dalam menyikapi teknologi infomasi, 3) Mengenalkan dan mengingatkan masyarakat kemungkinan dampak negatif yang dapat muncul dalam pemanfaatan teknologi informasi, 4) Meningkatkan daya nalar dan daya seleksi masyarakat terhadap berbagai informasi yang membanjir, sehingga masyarakat semakin kritis dan dewasa dalam menyikapinya.

Berikut ini ada beberapa tips ringan untuk memanfaatkan teknologi sehingga kita mendapatkan sebuah kualitas hubungan yang baik dengan teman-teman kita. Berikut adalah tipsnya : 
a. Gunakan teknologi yang anda kuasai untuk menjalin hubungan yang lebih intents dengan teman atau orang-orang yang sebelumnya telah anda kenal didunia nyata. Jangan terobsesi untuk mencari teman-teman baru di Facebook, twitter, atau social media yang lain karena kecenderungan yang terjadi, mereka yang hanya anda kenal didunia maya tidak akan memberikan nilai persahabatan yang mutualisme atau saling mensupport antara satu dan yang lain didunia nyata.

b. Jika anda ingin mencari teman-teman yang baru didunia maya, carilah komunitas positif yang sering melakukan pertemuan didunia nyata atau biasa dikenal dengan istilah kopdar atau kopi darat. Komunitas seperti inilah yang benar-benar akan mengasah kemampuan komunikasi anda karena komunitas-komunitas ini seringkali memberikan kita inspirasi dan dukungan yang optimal pada kehidupan anda.

c. Perlunya penegakkan hukum yang berlaku dengan dibentuknya polisi internet yang bertugas untuk menentukan standar operasi pengendalian dan penerapan teknologi informasi.

d. Menghindari pemakaian telepon seluler yang berfitur canggih oleh anakanak dibawah umur dan lebih mengawasi penggunaan telepon seluler.

e. Perbanyak membaca buku-buku yang bersifat edukatif.

f. Perbanyak membaca buku-buku yang menambah keimanan (religi).

g. Perbanyak aplikasi komputer yang bersifat mendidik.

h. Harus bisa mengatur waktu antara berada di depan komputer/internet atau bermain games dengan porsi belajar dan istirahat. Gunakan waktu seefektif dan seefisien mungkin.

i. Perlunya kewaspadaan terhadap tayangan televisi yaitu dengan : 1) Mewaspadai muatan pornografi, kekerasan, dan tayangan yang mengandung kekerasan, 2) Memperhatikan batasan umur peninton pada film yang sedang 
ditayangkan, 3) Mengaktifkan penggunaan fasilitas Parental Lock pada TV kabel dan Satelit, 4) Menghindari penempatan TV pribadi di dalam kamar.

j. Perlunya kewaspadaan terhadap penggunaan komputer dan internet, meliputi : 1) Mewaspadai muatan pornografi digital baik online maupun offline, 2) Mewaspadai kekerasan pada permainan / games komputer, 4) Cek history browser untuk melihat situs apa saja yang sudah dilihat oleh anak, 5) Menggunakan program pemblokir situs dan konten dewasa seperti Program filtering dan parental control, 6) Hindari penempatan komputer didalam kamar, letakkan komputer pada daerah yang mudah diawasi, 7) Hindari fasilitas internet jika komputer harus terpaksa diletakkan di kamar anak.

\section{PENUTUP}

Dalam kehidupan di jaman modern ini kita tidak akan bisa lari dari pengaruh perkembangan teknologi informasi dan komunikasi. Perkembangan teknologi informasi dan komunikasi telah banyak bermanfaat bagi kita baik di dalam pendidikan, bisnis, komunikasi lain, dan hiburan. Di samping manfaat-manfaat positif tersebut, perkembangan teknologi dan informasi memiliki dampak negatif. Dampak negatif tersebut hendaknya diminimalisasi dengan arif sehingga tidak menghilangkan dampak positifnya.

\section{DAFTAR PUSTAKA}

Ahmad Zein, 2010, Dampak Positif dan Negatif dari Internet, http:// community.gunadarma.ac.id/blog/view/id_9102/title_dampak-positif-dannegatif-dari-internet/

Wildan, 2008, Dampak Global Teknologi Informasi, http://wildan08.wordpress. com/2008/09/13/dampak-global-teknologi-informasi/

Yulliana Minerva, 2009, Dampak Negatif Teknologi Informasi dan Komunikasi, http://yesu.dagdigdug.com/2009/10/07/dampak-negatif- penggunaanteknologi-informasi-dan-komunikasi/ 
http://www.docstoc.com/docs/58252692/dampak-positif-dan-negatif-adanya-tik, Dampak Positif dan Negatif.

JPTK, UNDIKSHA, Vol. 8, No. 1, Januari $2011: 17$ - 28 